\title{
Silt production as a function of climate and lithology under simulated comminution
}

\author{
Gerilyn S. Soreghan*, Young Ji Joo, Megan E. Elwood Madden, Sarah C. Van Deventer
}

School of Geology and Geophysics, University of Oklahoma, 100 E. Boyd Street, Norman, Oklahoma, 73019, U.S.A.

*Corresponding Author: lsoreg@ou.edu

Keywords: silt, loess, comminution, lithology, climate, experimental

\section{Abstract}

Production of the silt-sized particles composing loess represents a critical step in its ultimate formation, but the volume and rate of production in different settings remain underdetermined. This study addresses the influence of climate and source lithology on silt formation by subjecting natural alluvial/fluvial sand from systems characterized by varying climatic setting to simulated comminution. Bulk samples from comparable transport distances were collected from a hot-arid (California desert) alluvial system, hot-humid (Puerto Rico) fluvial system, and cold-humid (Norway) proglacial fluvial system, and sieved to isolate the coarse-very coarse sand fraction for experimental milling. Source rocks in all three systems consist of granitoids, with some contributions from foliated coarse-grained metamorphic rocks (gneissic and schistose) in Norway. Results indicate that contributions from coarse-grained foliated lithologies impart a negligible effect on rate of silt production from the sand starting material. Climatic setting imparts no significant difference on sand durability, but influences clay production at later stages of comminution for the Puerto Rico sample, presumably owing to the effects of deep chemical weathering prior to physical transport. Comminution and silt production in all experiments exhibit exponential decay wherein rapid initial rates diminish with time. This is interpreted to reflect the effects of the dynamic milling conditions (particle size and distribution, and slurry viscosity), as well as particle strength, with the latter including both relative strengths of different minerals in general, and the influences of lattice defects and microfractures in quartz in particular. Empirical observations reveal that silt fractions of the natural alluvial/fluvial samples, collected at comparable transport distances $(5-7 \mathrm{~km})$ in the respective systems, exhibit significant 
differences. Bulk sediment samples from the Norwegian proglacial system contain substantially more silt (3 to 10 times) than either of the other two localities, implying a significant difference in the natural processes operating to generate silt in these different field settings. We suggest this difference reflects the efficacy of glacial grinding in silt production.

\section{Introduction}

The production of silt-sized particles represents a critical step in the ultimate formation of deposits of eolian silt known as loess. A number of processes lead to production of silt-sized material (4-62.5 $\mu \mathrm{m}$ for geologists), but the volume and rate of production in different settings remains underdetermined. .Loess is widely recognized as an excellent paleoclimate archive, and its finer $(<10 \mu \mathrm{m}$ dust) fraction additionally acts as an agent of climate change (e.g., Kukla et al., 1988; Porter and An, 1995; Mahowald et al., 2011). The loess of northern Serbia, for example, forms one of the thickest and most stratigraphically complete paleoclimate archives in Europe (Basarin et al., 2014). The spatial association of loess with formerly glaciated regions is generally attributed to the role of glacial grinding in producing voluminous fines in the silt mode (e.g., Kuenen, 1969; Smalley, 1966, 1990, 1995; Assallay et al., 1998; Muhs and Bettis, 2003), although the role of rivers in transporting and concentrating this material is also important (Smalley et al., 2009). Loess in Europe, for example, occurs primarily between the latitudes of $\sim 40-60^{\circ}$ in proximity to the margins and drainages of the former ice sheets (Muhs and Bettis, 2003; Haase et al., 2007). However, loess and "loess-like" sediments also occur in regions far removed from areas of Pleistocene glaciation, such as the peri-Saharan region (e.g., Yaalon, 1974; Coude-Gassen, 1987; Muhs and Bettis, 2003; Crouvi et al., 2010), suggesting non-glacial processes formed the fines within these loess deposits. For example, fluvial and eolian saltation and abrasion, as well as salt-, frost- and insolation weathering can also play roles in silt production (e.g. Nahon and Trompette, 1982; Pye, 1987; Assallay et al., 1998; Wright, 2001; Muhs and Bettis, 2003; Crouvi et al., 2010, 2012).

Perhaps the best-recognized accumulation of loess on Earth today - the Chinese Loess Plateau - constitutes the most complete Quaternary succession of loess known. This succession houses a paleoclimatic record that includes the impacts of northern hemisphere glaciation and attendant monsoonal variation at this site extending to $2.8 \mathrm{Ma}$, with the subjacent Red Clay succession extending to the Miocene (e.g., Kukla, 1987; Kukla et al., 1988; Sun et al., 1998; An 
et al., 2001; Sun, 2002). Owing in part to its location at generally lower latitudes $\left(35-40^{\circ}\right)$ than the European loess belts, and in proximity to large deserts, the origin of the silt composing this succession has been attributed to both glacial and desert mechanisms (e.g., Smalley, 1990, 1996; Sun, 2002). Hence, understanding the formation mechanisms of loess materials remains an important research question.

Some studies have attempted laboratory simulations of comminution to assess the roles of various types of physical weathering on silt production. These have included abrasion experiments simulating fluvial (Wright and Smith, 1993), eolian (Kuenen, 1960; Whalley et al., 1982, 1987; Smith et al., 1991; Bullard et al., 2004), and glacial abrasion (Wright, 1995, 1998 Jefferson et al., 1997; Kumar et al., 2006), as well as insolation, salt, and frost weathering (Moss et al., 1981; Pye and Sperling, 1983; Smith et al., 1987; Wright et al., 1998; Wright, 2001). These simulation studies applied a variety of apparatuses to simulate comminution in fluvial, eolian, or glacial settings, or weathering under simulated conditions. The starting materials used in simulated physical weathering studies comprised Brazilian vein quartz which had been freshly crushed to sand size (Whalley et al., 1982, 1987; Wright and Smith, 1993; Wright, 1995, 1998), weakly cemented Neogene sand (Smith et al., 1991), natural dune sand (Pye and Sperling, 1983; Bullard et al., 2004), or other natural sand (Jefferson et al., 1997), and the results varied widely.

Grain size of sediment is influenced to some degree by grain size of the starting material, even for first-cycle sediments. For example, in a study of in situ detritus formed on plutonic, gneissic, and schistose rocks, Blatt (1967) documented that mean size of quartz grains derived from the plutonic and gneissic lithologies exceeded that derived from schists by 1.5-2 times. Blatt (1970) further noted that first-cycle quartz entering the sedimentary cycle exhibits a mean grain size in the coarse sand mode $(670 \mu \mathrm{m})$, and suggested that fine-grained precursors such as slate and phyllite readily produce quartz silt on weathering. Palomares and Arribas (1993) echoed Blatt's (1967) earlier findings, noting much greater sand production as a result of mechanical weathering from granitoid than schistose starting compositions, owing to the larger crystal sizes and isotropy of granitoids. Similarly, Borrelli et al. (2014) documented that chemical weathering in granitoid and gneissic profiles within the same climatic region resulted in a soil residue characterized by a sand-gravel fraction for the granitoids and by both silt-clay and sand-silt fractions for the gneissic rocks. However, Wright (2002, 2007) suggested that 
significant amounts of silt can be produced within granitoid weathering profiles, simply by in situ physical comminution.

In light of the history on silt production research, the current study is motivated by two questions: First, in the case of crystalline (igneous or metamorphic) basement, does the foliation present in regionally metamorphosed (gneissic and coarse-grained schistose) rocks strongly affect the rate of silt production? That is, does this starting lithology influence durability, and thus silt production via simulated mechanical weathering? If so, then gneissic and schistose precursors may produce material in the silt fraction more readily than non-foliated (granitoid) precursors, under uniform conditions of simulated physical comminution. Secondly, does climate in which the sand-sized precursor material forms impart a preference in terms of rate of production of silt- or sand-sized material? If so then sand grains from climates characterized by strong chemical weathering, such as the tropics, may disintegrate more readily than sand grains in other climates.

To address these questions, we conducted experiments involving simulated physical weathering of natural sands collected from alluvial/fluvial systems of similar size, but differing in climatic setting. Additionally, although crystalline basement sources underlie all three settings, one system includes contributions from both plutonic and coarse-grained metamorphic (gneissic and schistose) lithologies. Our study differs from other published studies on experimental silt formation in the following ways: 1) the use of natural precursor material collected from alluvial/fluvial systems; 2) the restriction of that starting material to a size that falls within Blatt's (1970) average coarse sand mode thought typical of quartz entering the sedimentary cycle; and 3) use of natural material from sites characterized by very different climatic settings. Results contribute to our understanding of the lithologic and climatic dependence of silt-particle formation via physical weathering

\section{Methods}

\subsection{Field Areas}

We selected for sediment sampling alluvial-fluvial systems from three study sites that vary in climatic regime. These sites are: 1) a hot-arid alluvial system in Anza-Borrego Desert, southern California; 2) a hot-humid fluvial system of southeastern Puerto Rico; and 3) a cold-humid proglacial fluvial system in southern Norway (Fig. 1). The alluvial system of Anza Borrego 
experiences fluvial transport only during rare precipitation events sufficiently intense to generate overland flow. Given sufficient wind velocity, eolian transport might occur during dry conditions, but the position of the study area within a relatively protected "wineglass" valley (Remeika and Lindsay, 1992) mitigates against vigorous eolian processes here, and no sand dunes occur in the area. In southeastern Puerto Rico, the Rio Guyanes drains the tropical uplands and flows perennially with an average discharge of $\sim 2.02 \mathrm{~m}^{3} / \mathrm{s}$ (2013 data; USGS National Water Information System). In Norway, rivers in the adjacent Langedalen and Austerdalen valleys drain glaciers emanating from the Austerdalsbreen ice field and join to form the Storelvi River. Flow is perennial and peaks in late summer, with an average discharge comparable to that of the Rio Guyanes. Figure 2 illustrates the depositional settings of the three field sites.

Only crystalline basement rocks and modern alluvial deposits are exposed in the three sites. However, the bedrock lithology differs among the field sites, with unfoliated tonalite in California, granodiorite with minor metadiorite and metavolcanics in Puerto Rico, and both unfoliated and foliated granitoids in Norway (Fig. 2). Figure 1 and Table 1 summarize the key climatic and geologic attributes of these study sites, and Figure 3 displays photomicrographs of the bedrock in each locality. Sediment from the alluvial/fluvial systems was collected from bar surfaces within the alluvial/fluvial transects approximately $\sim 5-7 \mathrm{~km}$ from the headwater regions (Fig. 1), to standardize transport distances. Sampling sites were chosen to target the finestgrained part of the bar system (typically the downstream or slackwater portion of lateral bars).

\subsection{Laboratory Methods}

Samples were first wet-sieved to separate the gravel (>2 mm), sand $(2 \mathrm{~mm}-62.5 \mu \mathrm{m})$, and mud $(<62.5 \mu \mathrm{m})$ fractions. Subsequently, they were dry sieved to isolate the 500-1400 $\mu \mathrm{m}$ (coarse-very coarse sand) fraction. This fraction is naturally produced by the systems under study, and thus represents typical parent material in the proximal alluvial/fluvial system, of a mode $(800-1000 \mu \mathrm{m})$ that approximates the coarse sand mode typical of quartz entering the sedimentary cycle (Blatt, 1970). Because these are natural sediment systems, initial mode of the starting size fraction exhibits some variability amongst the three sites. The Puerto Rico sample exhibits the finest mode $(782 \mu \mathrm{m})$, followed closely by the Norway sample $(845 \mu \mathrm{m})$, whereas the Anza Borrego sample is less well sorted than the other two, with a slightly coarser mode (993 $\mu \mathrm{m})$ (Table 2). The mud fraction was additionally treated with buffered acetic acid $(\mathrm{pH} \sim 4.8)$ to 
remove carbonate and $30 \%$ hydrogen peroxide (several days) to remove organic matter. After rinsing thoroughly, the granulometry of the mud fraction was measured using a Malvern Mastersizer 3000 laser particle size analysis (LPSA) system.

For each coarse-very coarse sand sample, $2 \mathrm{~g}$ were introduced into a McCrone micronizing mill, together with de-ionized water, to simulate comminution in water. The mill vibrates the sand-sized sample material between grinding media, minimizing the shear force while reducing particle sizes to $<5 \mu \mathrm{m}$ after ten minutes of milling (O'Connor and Chang, 1986). The grinding medium consists of yttrium-stabilized zirconium oxide beads $\left(95 \% \mathrm{ZrO}_{2}\right)$. For these experiments, we used short-duration mill times, and varied the milling time to investigate the size distributions produced after different durations, and assess the rate of disintegration of sand, and subsequent production of silt and mud.

Samples were milled for 5, 10, 15, 30, 45, 60 or 300 seconds. Following each timed run, all sample material was extracted from the mill. Samples were then treated with 2-3 drops of sodium hexametaphosphate (dispersant) prior to grain-size analysis using a Malvern Mastersizer 3000 LPSA. Silt fraction for these samples was determined from the LPSA data.

The choice of a micronizing mill for the comminution is not meant to simulate a particular physical weathering mechanism (e.g. fluvial saltation, subglacial grinding, or eolian abrasion). Rather, it simply enables uniform application of a given type of (simulated) physical comminution over preset durations. Varying the (natural) starting material and the climatic settings of this material then enables assessment of the relative durabilities of these natural starting materials, as prescribed by lithology and climate-controlled "preweathering."

\section{Results}

\subsection{Granulometry of the Natural Sediments}

Figure 4 shows the gravel-sand-mud distributions of the natural (bulk) samples as initially collected, showing that all three are sand dominated, although the Anza Borrego sample contains a greater proportion of gravel than the other two. The Anza Borrego sample exhibits the smallest mud fraction (4.1\%), whereas the Puerto Rico and Norway samples have mud fractions of $7.4-8.0 \%$. Isolating the silt fraction reveals that the Norway sample contains the largest amount of silt (7.7\%), followed by the PR sample (5.9\%), whereas the Anza Borrego sample has the least silt (3.4\%). Table 2 summarizes these data, and also shows average percentages of 
sediment size fractions for the most proximal $\sim 4-11 \mathrm{~km}$ of the fluvial/alluvial transect for each locality. These averages are likely more instructive for characterizing natural variability within and among the three sites, as differences related to transport distance and local sampling variations are minimized. Using this approach, the Norway samples contain the largest amount of silt (13.9\%) on average, followed by the Puerto Rico sample averages at 4.6\%, and the Anza Borrego sample averages at $2.4 \%$.

\subsection{Rates of Disintegration of Coarse Sand}

Rate of disintegration of the starting sand fraction displays no significant differences among the three samples (Figs. 5, 6A; Table 3). Calculated initial rates of silt formation based on silt percentages observed during the first 60 seconds of milling do not vary significantly among lithologic types or climatic stetting. This suggests that there is essentially no, or minimal significant difference in durability amongst the natural starting materials for all three samples.

\subsection{Rates of Comminution and Silt Production}

For all samples, rates of comminution follow exponential decay functions wherein initially rapid rates of comminution and silt production generally diminish with milling time over the duration of the experiments. Specifically, for samples from all three localities, rapid production of silt occurs in the first $10-15 \mathrm{~s}$, with $>50 \%$ of the sand converted to silt or clay within the first $15 \mathrm{~s}$ of milling (Fig. 6B). The rate of silt production slows thereafter, but the percentage of silt continues to increase after 30-60 s of milling. Some variability occurs in rates among sites, but is relatively minimal. By the $300 \mathrm{~s}$ mark, silt percentage in all three sites decreased, as comminution progressed sufficiently for the silt to disintegrate further to produce clay $(<4 \mu \mathrm{m})$. This is most pronounced for the Puerto Rico sample, although major inter-sample differences do not occur.

\section{Discussion}

\subsection{Influence of Starting Lithology on Sand Durability and Potential for Silt Production}

Both the Puerto Rico (PR) and Anza Borrego (AB) bedrock comprise predominantly igneous crystalline material ( $\mathrm{PR}$ - granodiorite and minor metadiorite; $\mathrm{AB}$ - tonalite); such

isotropic plutonic rocks are generally considered more durable than foliated (schistose and 
gneissic) metamorphic rocks, owing to the fabric heterogeneities that impart additional unstable surfaces in the latter (Palomares and Arribas, 1993), as well as the more highly stressed quartz in metamorphic rocks (O'hara-Dhand et al., 2010). Accordingly, one might expect mechanical disintegration to proceed at the fastest rate for the foliated rock types, but our results refute this assumption. Overall, we infer that the inclusion of foliated lithologies in the Norway site does not confer a significant difference in rates of silt production, albeit the slightly higher initial rate for the Norway sample likely does reflect a minor influence of finer-grained schistose lithologies. We interpret this result to indicate that the effect of foliation on the (relatively coarse-grained) parent material imparts a negligible effect on rate of silt production with simulated comminution (i.e., simulated mechanical weathering).

Previous studies on experimental comminution have shown conflicting results regarding the efficacy of different mechanisms for silt production (Table 4). Both Smalley et al. (2005) and Kumar et al. (2006) noted the contrasting results of eolian abrasion experiments (Kuenen, 1960 and Whalley et al., 1982) and suggested a possible lithological control emanating from the starting materials. Kumar (2006) tested this by replicating the glacial grinding experiments of Wright (1995), using the same grinding apparatus as Wright (1995), but with (uncemented) Cretaceous sand as a starting material instead of vein quartz. In contrast to Wright's (1995) results of no silt production, Kumar et al. (2006) found substantial silt production. Kumar et al. (2006) posited that vein quartz lacks the crystallographic defects ("Moss defects") common in plutonic quartz (see also Smalley et al., 2005). Our results demonstrate the ease of silt production from natural materials, and potentially corroborate the inference of Smalley et al. (2005) and Kumar et al. (2006) regarding the positive influence of crystallographic defects on fracturing and comminution.

\subsection{Influence of Climatic Setting on Sand Durability}

The lack of influence of the climatic setting on sand durability is somewhat counterintuitive; one might hypothesize that sand from the tropical system (PR) would disintegrate faster owing to intense chemical weathering that occurs prior to sediment introduction into the fluvial system. Specifically, the hot, humid, montane environment of eastern Puerto Rico promotes pervasive and extremely rapid chemical weathering (e.g., White et al., 1998). The regolith (soil plus saprolite) in eastern Puerto Rico ranges up to $8 \mathrm{~m}$ thick, and oxidation of 
biotite initiates fracturing that enables the abundant water available to reach minerals deeper within the regolith-bedrock interface (Buss et al., 2008). Accordingly, the sediment (sand and gravel) transported into the rivers is chemically weathered and presumably weakened, theoretically enabling mechanical weathering to proceed at an accelerated pace for sand here relative to sand in the cool-wet and hot-dry climates of the other two systems. This climatic setting does not impart a significant difference on sand durability.

\subsection{Rates of Comminution}

Comminution and silt production in all experiments with all samples exhibit exponential decay from 0-300 s, wherein rapid initial rates yield with time to slower rates, followed ultimately by a decrease in silt production as silt disintegrates to clay beyond the $60 \mathrm{~s}$ mark. These results corroborate those of Jefferson et al. (1997), who inferred that such rate discontinuities of silt production in comminution experiments likely signal the breach of a defect-controlled energy level. That is, that initial grinding exploits inherent defects in quartz crystals resulting in relatively rapid initial breakage. Such defects characterize plutonic quartz (e.g., Bernet and Bassett, 2005), as sets of microfractures formed during cooling, acting to control the durability and degree of ready comminution (Moss, 1966; Moss and Green, 1975). Further comminution then slows owing to the emergence of defect-free quartz below the size limit of these micro fractures ( $<20 \mu \mathrm{m}$; Moss and Green, 1975). Metamorphic quartz contains deformation-induced microfractures and lamellae. These microfractures persist in low- to moderate-grade metamorphic quartz, but microfractures and crystallographic discontinuities are rare in vein quartz (Bernet and Bassett, 2005).

Certainly, quartz grains contain lattice defects, linked to attributes such as water content (e.g. hydrolytic weakening), trace elements, or metamorphic stresses (e.g. Stalder and Konsett, 2012) that presumably enhance breakage. Additionally, however, the rates of silt production in our experiments may reflect the influence of the milling environment. Verma and Rajamani (1995) demonstrated that experimental breakage rates evolve according to the particle size distribution in a milling environment. This evolution relates to several factors, including the number of contact forces, particle size and particle size distribution, particle strength, and viscosity of the grinding slurry (in wet milling). All of these factors excepting particle strength evolve as grinding proceeds. So, e.g., under wet-milling conditions, breakage rates of coarse 
particles increase as fines are generated, because the presence of fine-grained products enhances breakage of the remaining coarse material. However, production of fines also increases the viscosity of the slurry, which then ultimately decreases breakage by cushioning particles once viscosity increases sufficiently.

Additionally, as grinding begins, weaker particles break first, with breakage enhanced by crushing between more resistant particles such as quartz. Therefore differences in mineral hardness lead to differences in susceptibility to comminution (Haldorsen, 1983). For example, Jari (1995) documented a mineralogical (and thus geochemical) fractionation that occurred during experimental milling, reflecting enhanced comminution in the order mica>amphibole>feldspar>quartz. Similarly, working with subglacial till, Yi (1997) documented preferential breakage of mica (chlorite) relative to feldspar and quartz. Hence, our results likely reflect preferential breakage of weak minerals (mica, mafics) initially, providing fines to further enhance breakage, followed by quartz breakage, and an ultimate reduction in breakage as the viscosity of the slurry increased with increased fines production.

Additionally, the differences in proportion of clay among the samples after $300 \mathrm{~s}$ of milling signal an inter-sample difference. Specifically, the significantly greater ( $>50 \%$ more) clay-sized fraction in the Puerto Rico sample relative to the other two samples after $300 \mathrm{~s}$ of milling suggests the influence on chemical weathering on long-term comminution. That is, the effect of pre-weathering of these samples in the hot-humid climate acts to enhance disintegration to clay sizes in later stages of physical comminution in the Puerto Rico sample.

\subsection{Comparison of Simulated Silt Production and Silt Fraction of Natural Sediments}

These experimental results conducted on natural sands from plutonic and coarse-grained metamorphic sources indicate that silt is produced at similar rates when subjected to the same type of physical milling. Furthermore, climate does not impart a significant control on physical sand durability in these systems, but appears to influence clay production at later stages of comminution. However, the fraction of silt in the natural field samples differ significantly, with Norway samples containing on average 3 to 7 times the amount of silt relative to the Puerto Rico and Anza Borrego samples (Table 2), with one Norway sample containing 25\% silt. This pattern prevails despite the chemically weathered starting material of the Puerto Rico samples. 
Some authors have inferred a substantial role for chemical weathering in producing silt. Nahon and Trompette (1982) suggested that weathering processes, especially in tropical regions constitute the primary means to generate silt. Weak minerals disappear by dissolution, and weathering solutions follow discontinuities and microfractures (including crystallographic defects) in quartz to reduce larger grains to silt size (Nahon and Trompette, 1982; Wright, 2002). Our empirical results refute this, in that the Puerto Rico samples contain only a minor silt fraction of (on average) 4.6\%, slightly more than twice the Anza Borrego samples, and significantly less than the $14 \%$ average of the Norway samples.

The starting lithology in all three systems - relatively coarse-grained igneous and metamorphic rocks, all contain plutonic quartz with crystallographic defects and/or microfractures typical of metamorphic quartz, and thus are relatively equivalent in their potential to liberate silt, given the appropriate fracturing forces. The Norway and Puerto Rico samples both contain minor contributions from finer-grained metamorphosed lithologies (Fig. 3D, 3F), but the substantial (2-14\%) difference in the average amount of silt in the natural systems collected from each locality implies a significant difference in the natural processes operating to generate silt grain sizes in these different field settings. The natural processes conceivably operating in these systems are primarily: 1) glacial grinding in Norway; 2) vigorous and essentially perennial fluvial transport in both Norway and Puerto Rico; 3) ephemeral flash-flood transport in Anza Borrego; and 4) eolian transport in Anza Borrego. The Anza Borrego locality produces minimal silt from the coarse-grained precursor material presumably owing to the rarity of fluvial and eolian processes and absence of glacial weathering in this system. The silt contribution in the Puerto Rico samples likely reflects 1) tropical weathering in the regolith prior to sediment transport into the stream system, 2) vigorous fluvial transport, and 3) perhaps some contribution from the minor metavolcanic component here. However, the empirical data from the natural samples do not support a major role for chemical weathering that weakens the sand and/or quartz in particular to cause fracturing to silt in large volumes, a finding that contrasts with Nahon and Trompette (1982) and Wright (2002). Neither can we call upon large differences in stream transport energy, as the fluvial systems in both Puerto Rico and Norway are of comparable sizes and discharges (Fig. 2). Our empirical data set indicates that the major difference relates to the action of glacial grinding in the Norwegian locality. This result reconfirms earlier suggestions by many authors of the efficacy of glacial processes in generating 
large volumes of sediment in the silt mode (Bryan, 1945; Smalley, 1966; Kuenen, 1969; Boulton, 1978; Smalley and Smalley, 1983; Pye, 1987; Smalley, 1990, 1995; Assallay et al., 1998; Muhs and Bettis, 2003).

\section{Conclusions}

Use of sand isolated from natural sediments for comminution experiments, and comparison of results with empirical data on the natural bulk samples from the same systems shed light on silt-production capacity related to climate, and source lithology. When subjected to a fixed type of simulated physical weathering, sand derived from entirely granitoid bedrock produces silt at a rate indistinguishable from sand derived from lithologies that include gneiss and coarse-grained schist. Rates of grain breakage and consequent fines production for all samples follow an exponential decay function. This pattern likely relates at least in part to the occurrence of lattice defects and microfractures in the igneous and metamorphic quartz of these relatively coarse-grained crystalline precursors, but also reflects the dynamic conditions of the milling environment (particle size, size distribution, and slurry viscosity), as well as particle strength, with weaker minerals breaking first. Additionally, these findings suggest that simulated comminution conducted using vein quartz may produce results unrepresentative of most natural source materials.

While climatic setting of the natural precursor sand did not significantly influence silt formation, climate does appear to influence clay production. Specifically, the chemical "preweathering" of both the bedrock and derivative sand that occurs in tropical climates such as Puerto Rico appear to prime sediment for clay production with progressive physical weathering.

The significant differences in the silt fractions of the bulk natural samples contrast greatly with the negligible differences in silt production capacity revealed by the simulations. When controlled for distance of stream transport, bulk sediment samples from the Norwegian proglacial system contain up to an order of magnitude more silt than either of the other two localities. This cannot be explained by the silt production capacity of the different lithologies involved, nor by a large difference in stream capacity in the comparably sized fluvial systems of Puerto Rico and Norway. Hence, this appears to reflect a real and significant difference in the capacity of the system to physically weather the source material to silt. The only mechanism unique to the Norwegian setting is the presence of upland ice feeding valley glaciers drained by 
the sampled fluvial systems. We thus suggest that the silt richness of the Norway samples relates to the efficacy of glacial grinding in silt production.

\section{Acknowledgments}

Funding for this research was provided by the National Science Foundation (EAR-12252162, EAR-1338331, with instrumentation from EAR-1418716), and the Petroleum Research Fund of the American Chemical Society (PRF \#52114-ND8). Any opinions, findings, and conclusions or recommendations expressed in this material are those of the authors and do not necessarily reflect the views of the funding agencies. We thank B. Pritchett and A. Elwood Madden for laboratory assistance, and the reviewers and editors of Quaternary International for constructive comments on an earlier version of this manuscript.

\section{References}

An, Z.S., Kutzbach, J.E., Prell, W.L., Porter, S.C., 2001. Evolution of Asian monsoons and phased uplift of the Himalaya-Tibetan plateau since late Miocene times. Nature 411, 62-66.

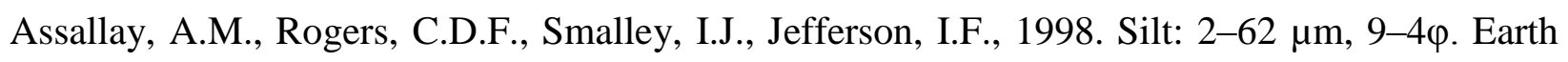
Science Reviews 45, 61-88.

Basarin, B., Buggle, B., Hambach, U., Markovic, S.B., O-Hara Dhand, K., Kovacevic, A., Stevens, T., Guo, Z., and Lukic, T., 2014. Time-scale and astronomical forcing of Serbian loess-paleosol sequences. Global and Planetary Change 122, 89-106.

Bernet, M., and Bassett, K., 2005. Provenance analysis by single-quartz-grain SEM-CL/optical microscopy. Journal of Sedimentary Research, 75, 492-500.

Blatt, H., 1967. Original characteristics of clastic quartz grains. Journal of Sedimentary Petrology 37, 401-424.

Blatt, H., 1970. Determination of Mean Sediment Thickness in the Crust: A Sedimentologic Method. Geological Society of America Bulletin 81, 255-262.

Borrelli, L., Perri, F., Critelli, S., Gullà, G., 2014. Characterization of granitoid and gneissic weathering profiles of the Mucone River basin (Calabria, southern Italy). Catena 113, 325340.

Boulton, G.S., 1978. Boulder shapes and grain-size distributions of debris as indicators of transport paths through a glacier and till genesis. Sedimentology 25, 773-799. 
Bryan, K., 1945. Glacial versus desert origin of loess. American Journal of Science 243, 245246.

Bullard, J.E., McTainsh, G.H., Pudmenzky, C., 2004. Aeolian abrasion and modes of fine particle production from natural red dune sands: an experimental study. Sedimentology 51, 1103-1125.

Buss, H., Sak, P., Webb, S., and Brantley, S., 2008. Weathering of the Rio Blanco quartz diorite, Luquillo Mountains, Puerto Rico: Coupling oxidation, dissolution, and fracturing. Geochimica et Cosmochimica Acta 72, 4488-4507.

Coudé-Gaussen, G., 1987. The Perisaharan loess: sedimentological characterization and paleoclimatical significance. GeoJournal 15, 177-183.

Crouvi, O., Amit, R., Enzel, Y., 2010. Active sand seas and the formation of desert loess. Quaternary Science Reviews 29, 2087-2098.

Crouvi, O., Schepanski, K., Amit, R., Gillespie, A.R., and Enzel, Y., 2012. Multiple dust sources in the Sahara Desert: The importance of sand dunes. Geophysical Research Letters 39, L13401, doi: 10.1029/2012GL052145.

Haase, D., Fink, J., Haase, G., Ruske, R., Pésci, M., Richter, H., Altermann, M., and Jager, K.D., 2007. Loess in Europe-its spatial distribution based on a European Loess Map, scale 1:2,500,000. Quaternary Science Reviews 26, 1301-1312.

Haldorsen, S., 1983. Mineralogy and geochemistry of basal till and its relationship to tillforming processes. Norsk Geologisk Tidsskrift 63, 15-25.

Jari, M., 1995, Effects of grinding and chemical factors on the generation and composition of the till fine fraction: an experimental study. Journal of Geochemical Exploration 54, 49-62.

Jefferson, I.F., Jefferson, B.Q., Assallay, A.M., Rogers, C.D.F., and Smalley, I.J., 1997. Crushing of quartz sand to produce silt particles. Naturwissenschaflen 84, 148-149.

Kuenen, P.H., 1960. Experimental abrasion 4: eolian action. Journal of Geology 68, 427-449.

Kuenen, P.H., 1969. Origin of quartz silt. Journal of Sedimentary Petrology 39, 1631-1633.

Kukla, G., 1987. Loess stratigraphy in central China. Quaternary Science Reviews 6, 191-219.

Kukla, G., Heller, F., Liu, X.M., Xu, T.C., Liu, T.S., and An, Z.S., 1988. Pleistocene climates in China dated by magnetic susceptibility. Geology 16, 811-814.

Kumar, R., Jefferson, I.F., O’Hara-Dhand, K., and Smalley, I.J., 2006. Controls on quartz silt formation by crystalline defects. Naturwissenschaflen 93, 185-188. 
Mahowald, N., Ward, D.S., Kloster, S., Flanner, M.G., Heald, C.L., Heavens, N.G., Hester, T., Lamarque, J.-F., and Chuang, P.Y., 2011. Aerosol impacts on climate and biogeochemistry. Annual Review of Environmental Resources 36, 45-74.

Lutro, O. and Tveten, E., 1996. Geological map of Norway, berggrunskart Årdal M 1:250,000 . Geological Survey of Norway.

Moss, A.J., 1966. Origin, shaping and significance of quartz sand grains. Journal of the Geological Society of Australia 13, 97-136.

Moss, A.J., Green, P., 1975 Sand and silt grains: predetermination of their formation and properties by microfractures in quartz. Journal of the Geological Society of Australia 22, 485-495.

Moss, A.J., Gren, P., and Hutka, J., 1981. Static breakage of granitic detritus by ice and water in comparison with breakage by flowing water. Sedimentology 28, 261-272.

Muhs, D.R., Bettis III, E.A., 2003. Quaternary loess-paleosol sequences as an example of climatic extremes. Geological Society of America Special Paper 370, 53-74.

Nahon, D., and Trompette, R., 1982. Origin of siltstones: glacial grinding versus weathering. Sedimentology 29, 25-35.

O’Hara-Dhand, K., Taylor, R.L.S., Smalley, I.J., Krinsley, D.H., Vita-Finzi, C., 2010. Loess and dust on Earth and Mars: particle generation by impact mechanisms. Central European Journal of Geosciences 2, 45-51.

O'Connor, B. H. and Chang, W.-J., 1986. The amorphous character and particle size distributions of powders produced with the Micronizing Mill for quantitative x-ray powder diffractometry. X-Ray Spectrometry 15, 267-270.

Palomares, M., Arribas, J., 1993. Modern stream sands from compound crystalline sources: Composition and sand generation index. Geological Society of America Special Paper 284, 313-322.

Porter, S.C., and An, Z., 1995. Correlation between climate events in the North Atlantic and China during the last glaciation. Nature 375, 305-308.

Pye, K., 1987. Aeolian Dust and Dust Deposits. Academic Press, London, 312 p.

Pye, K., and Sperling, C.H.B., 1983. Experimental investigation of silt formation by status breakage processes: the effect of temperature, moisture, and salt on quartz dune sand and granitic regolith. Sedimentology 30, 49-62. 
Remeika, P. and Lindsay, L., 1992. Geology of Anza-Borrego: edge of creation. Sunbelt Publications, San Diego.

Rogers, C.L., Cram, C.M., Pease Jr, M.H. and Tischler, M.S., 1979. Geologic map of the Yabucoa and Punta Tuna quadrangles, Puerto Rico. U.S. Geological Survey Miscellaneous Geologic Investigations Map I, San Diego.

Smalley, I.J., 1966. The properties of glacial loess and the formation of loess deposits. Journal of Sedimentary Petrology 36, 669-676.

Smalley, I.J., 1990. Possible formation mechanisms for the modal coarse silt quartz particles in loess. Quaternary International 7/8, 23-27.

Smalley, I.J., 1995. Making the material; the formation of silt-sized primary mineral particles for loess deposits. Quaternary Science Reviews 14, 645-651.

Smalley, I.J., Smalley, V., 1983. Loess material and loess deposits: formation, distribution, and consequences. In: Brookfeld, M.E., Ahlbrandt, T.S. (Eds.), Eolian Sediments and Processes. Elsevier, Amsterdam, pp. 51-68.

Smalley, I.J., Kumar, R., O'Hara Dhand, K., Jefferson, I.F., and Evans, R.D., 2005. The formation of silt material for terrestrial sediments: Particularly loess and dust. Sedimentary Geology 179, 321-328.

Smalley, I., O’Hara-Dhand, K., Wint, J., Machalett, B., Jary, Z., and Jefferson, I., 2009. Rivers and loess: The significance of long river transportation in the complex event-sequence approach to loess deposit formation. Quaternary International 198, 7-18.

Smith, B.J., McGreevy, J.P., Whalley, W.B., 1987. Silt production by weathering of a sandstone under hot arid conditions: an experimental study. Journal of Arid Environments 12, 199-214.

Smith, B.J., Wright, J.S., and Whalley, W.B., 1991. Simulated aeolian abrasion of Pannonian sands and its implications for the origins of Hungarian loess. Earth Surface Processes and Landforms $16,745-752$.

Stalder, R., and Konzett, J., 2012, OH defects in quartz in the system quartz-albite-water and granite-water between 5 and 10 kbar. Physics and Chemistry of Minerals 39, 817-827.

Strand, R.G., 1962. Geologic Map of California: San Diego-El Centro Sheet. California Division of Mines and Geology. 
Sun, D.H., Shaw, J., An, Z.S., Cheng, M.Y., Yue, L.P., 1998. Magnetostratigraphy and paleoclimatic interpretation of continuous 7.2 Ma late Cenozoic aeolian sediments from the Chinese Loess Plateau. Geophysical Research Letters 25, 85-88.

Sun, J., 2002. Provenance of loess material and formation of loess deposits on the Chinese Loess Plateau. Earth and Planetary Science Letters 203, 845-859.

Whalley, Marshall, J.R., and Smith, B.J., 1982. Origin of desert loess from some experimental observations. Nature 300, 433-435.

Whalley, W.B., Smith, B.J., McAlister, J.J., and Edwards, A.J., 1987. Aeolian abrasion of quartz particles and the production of silt-size fragments: preliminary results. In Frostick, L., and Reid, I., eds., Desert Sediments: Ancient and Modern. Geological Society, London, Special Publication 35, 129-138.

White, A., Blum, A., Schulz, M., Vivit, D., Stonestrom, D., Larsen, M., Murphy, S., and Eberl, D., 1998. Chemical Weathering in a Tropical Watershed, Luquillo Mountains, Puerto Rico: I. Long-Term Versus Short-Term Weathering Fluxes. Geochimica et Cosmochimica Acta 62, 209-226.

Wright, J., and Smith, B.J., 1993. Fluvial comminution and the production of loess-sized quartz silt: A simulation study. Geografiska Annaler 75, 25-34.

Wright, J.S., 1995. Glacial comminution of quartz sand grains and the production of loessic silt: A simulation study. Quaternary Science Reviews 14, 669-680.

Wright, J.S., 2001. Making loess-sized quartz silt: data from laboratory simulations and implications for sediment transport pathways and the formation of "desert" loess deposits associated with the Sahara. Quaternary International 76/77, 7-19.

Wright, J.S., 2002. Granitoid weathering profiles as a source of loessic silt. Transactions, Japanese Geomorphological Union. 23-5, 769-793.

Wright, J.S., 2007. An overview of the role of weathering in the production of quartz silt. Sedimentary Geology 202, 337-351

Wright, J., Smith, B., Whalley, B., 1998. Mechanisms of loess-sized quartz silt production and their relative effectiveness: laboratory simulations. Geomorphology 23, 15-34.

Yaalon, D.H., 1974. Accumulation and distribution of loess-derived deposits in the semi-desert and desert fringe areas of Israel. Geomophology 20, 91-105. 
Yi, C.L., 1997. Subglacial comminution in till—evidence from microfabric studies and grainsize distributions. Journal of Glaciology 43, 473-479.

\section{Tables}

Table 1: Climatic and Geologic Attributes

Table 2: Granulometry of natural samples

Table 3: Results of micronizing experiments

Table 4: Summary of previous studies

\section{Figure Captions}

Figure 1: Location map showing bedrock lithologies and alluvial-fluvial systems of A) Anza Borrego (modified after Strand, 1962); B) Norway (modified after Lutro and Tveten, 1996); and C) Puerto Rico (modified after Rogers et al., 1979). Collection sites for the samples used in the comminution experiments are indicated by a small circle.

Figure 2: Field photos illustrating the depositional settings and bedrock lithologies of the three localities: A, B) Anza Borrego; C,D) Norway; E, F) Puerto Rico.

Figure 3: Thin section photomicrographs of typical bedrock starting material in the three localities: A, B) Anza Borrego (tonalite, A - cross-polarized light, B - plane light). C, D) Norway (C - granodiorite; D - gneiss; both in cross-polarized light). E, F) Puerto Rico (E granodiorite; D - metadiorite; both in cross-polarized light).

Figure 4: Gravel - sand - mud ternary plot of natural bulk samples from the three localities.

Figure 5: Grain size histograms of experimentally comminuted material from all three sites, showing results from each time step: A) Anza Borrego; B) Norway; C) Puerto Rico.

Figure 6: Rate of A) sand disintegration and B) silt production. 
Figure 1
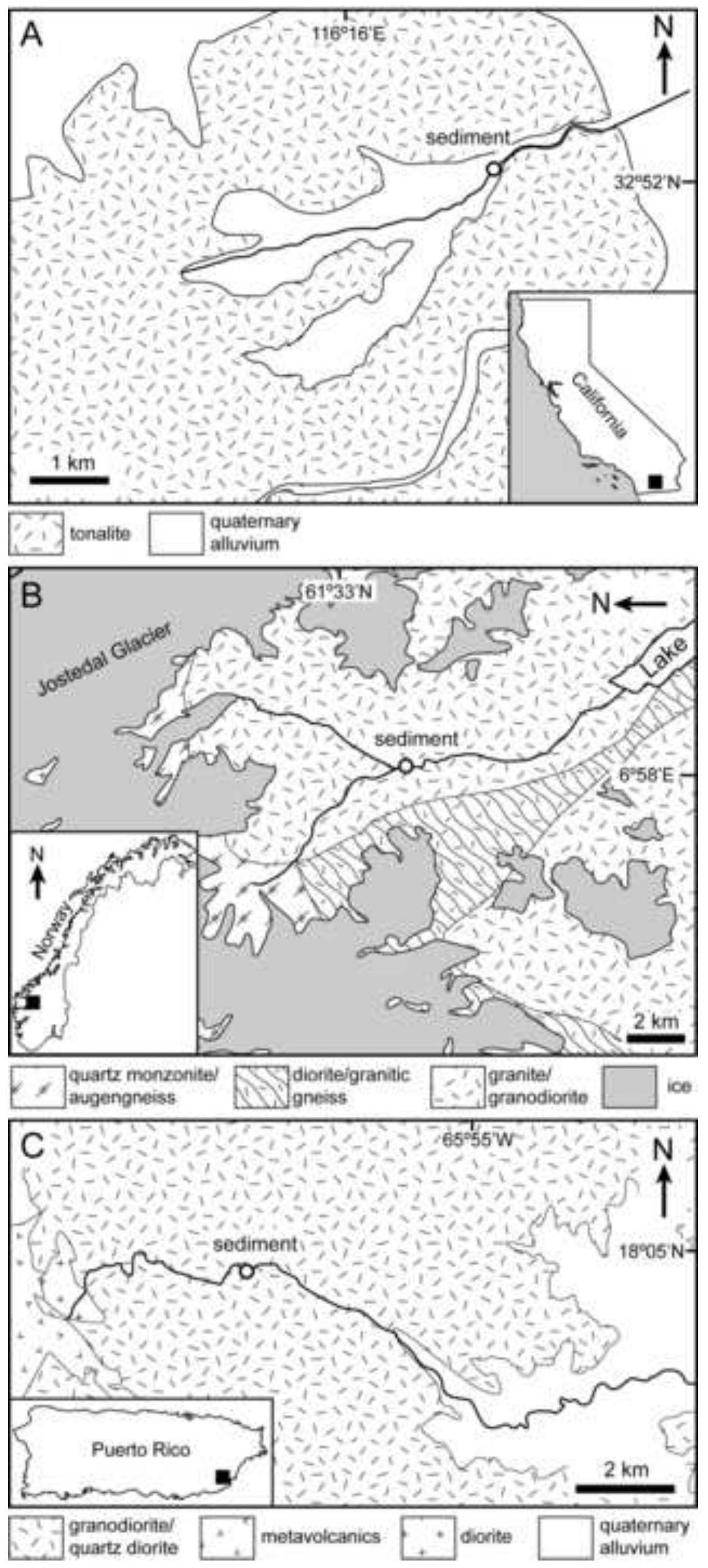

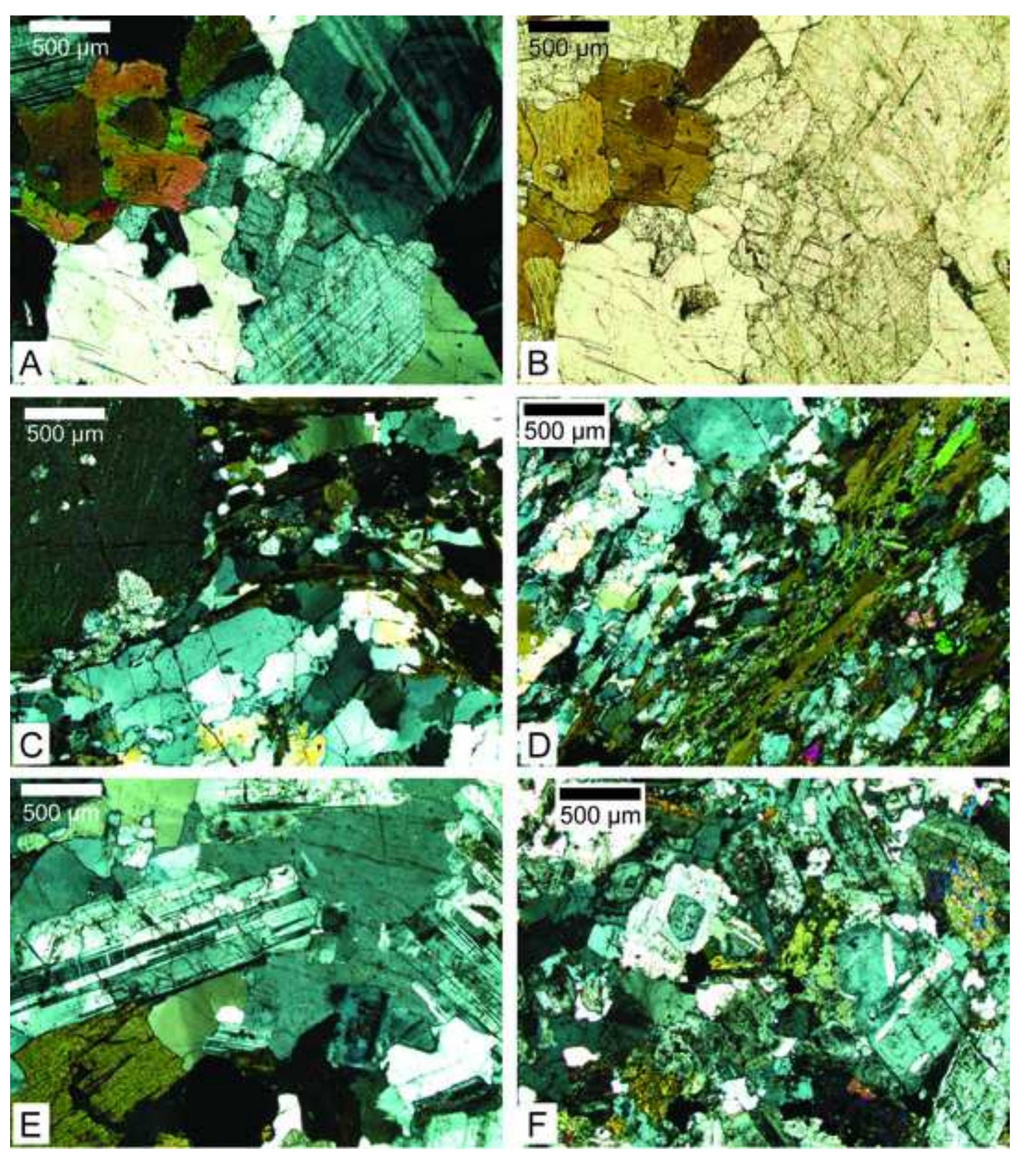

\section{Figure}

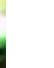

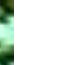
政

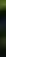

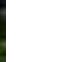

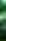

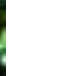

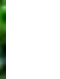

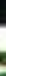




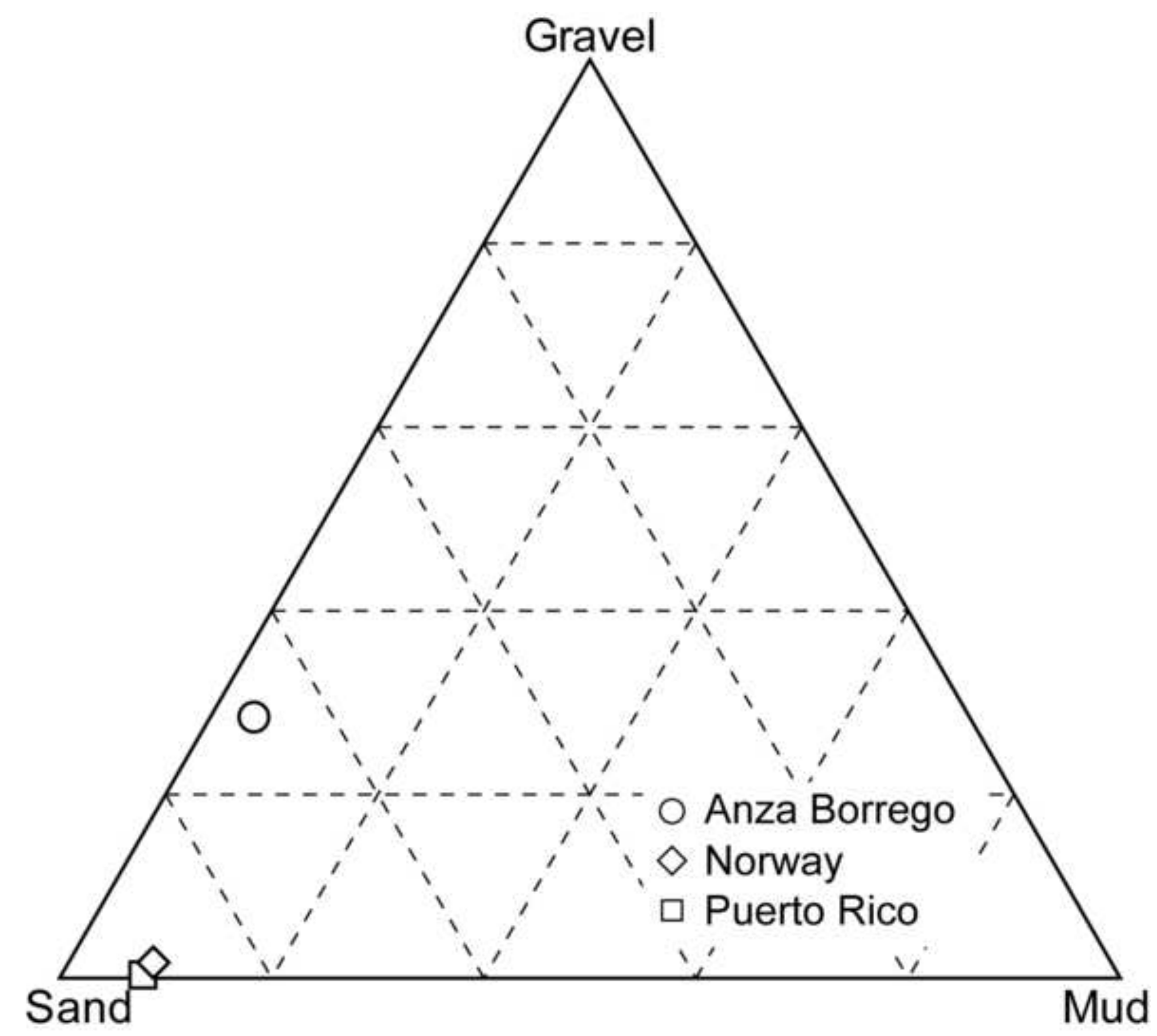


Figure 5
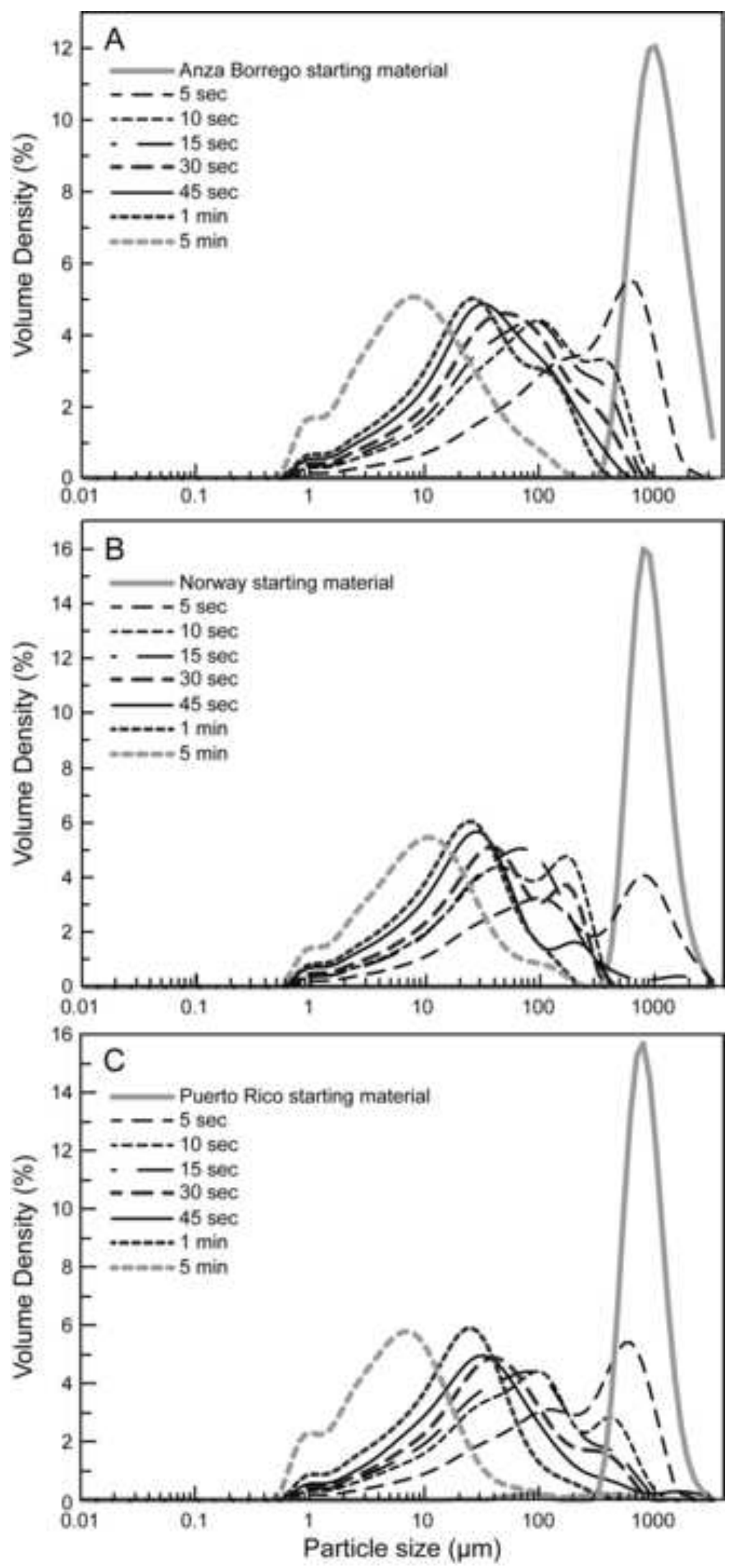

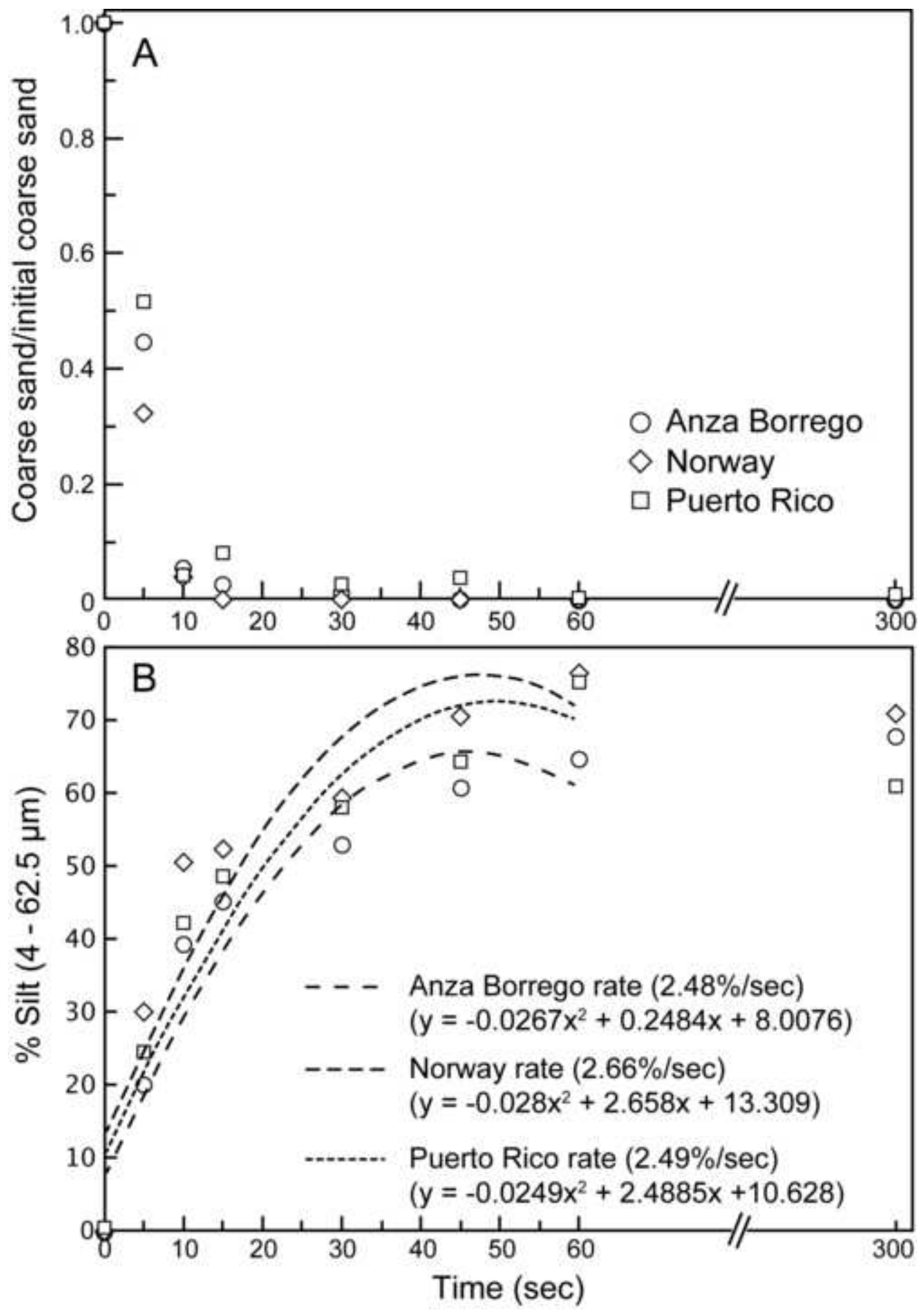
Table 1. Sample site characteristics.

\begin{tabular}{|c|c|c|c|c|c|c|}
\hline & Climate & Bedrock lithology & MAT $\left({ }^{\circ} \mathrm{C}\right)$ & $\begin{array}{l}\text { MAP } \\
(\mathrm{mm})\end{array}$ & $\begin{array}{l}\text { Relief } \\
(\mathrm{m})\end{array}$ & $\begin{array}{l}\text { Distance } \\
(\mathrm{km})\end{array}$ \\
\hline Anza Borrego & $\begin{array}{l}\text { Hot, } \\
\text { arid }\end{array}$ & Tonalite $(100 \%)$ & 23 & 150 & 779 & 5.2 \\
\hline Norway & $\begin{array}{l}\text { Cold, } \\
\text { humid }\end{array}$ & $\begin{array}{l}\text { Quartz monzonite - partly } \\
\text { metamorphosed to augen gneiss } \\
(49 \%) \text { granodiorite }(41 \%) \text {, granitic } \\
\text { gneiss }(9 \%),\end{array}$ & 4.5 & 1769 & 1659 & 7.3 \\
\hline Puerto Rico & $\begin{array}{l}\text { Hot, } \\
\text { humid }\end{array}$ & $\begin{array}{l}\text { Granodiorite }(65 \%) \text {, } \\
\text { metavolcanics }(27 \%) \text {, diorite }(8 \%)\end{array}$ & 22 & 4200 & 372 & 6.6 \\
\hline
\end{tabular}


Table 2. Granulometry of natural samples used for the micronizing experiment and average of 3 natural sediment samples in each locality.

\begin{tabular}{|c|c|c|c|c|c|c|c|}
\hline & \multirow[t]{2}{*}{ Distance $(\mathrm{km})$} & \multirow[t]{2}{*}{$\%$ Gravel } & \multirow[t]{2}{*}{$\%$ Sand } & \multicolumn{3}{|c|}{$\%$ Mud $(<62.5 \mu \mathrm{m})$} & \multirow[t]{2}{*}{ Silt mode $(\mu \mathrm{m})$} \\
\hline & & & & $\begin{array}{c}\% \text { Silt } \\
(4-62.5 \mu \mathrm{m})\end{array}$ & $\begin{array}{l}\text { \% Clay } \\
(<4 \mu \mathrm{m})\end{array}$ & Total & \\
\hline \multicolumn{8}{|c|}{ Samples used for experiment } \\
\hline $\mathrm{AB}$ & 5.2 & 28.4 & 67.4 & 3.4 & 0.7 & 4.1 & 50.2 \\
\hline NOR & 7.3 & 1.7 & 90.4 & 7.7 & 0.3 & 8.0 & 45.6 \\
\hline PR & 6.6 & 0.9 & 91.7 & 5.9 & 1.5 & 7.4 & 50.2 \\
\hline \multicolumn{8}{|c|}{ Average of three adjacent samples } \\
\hline $\mathrm{AB}$ & $5.2-8.3$ & 24.5 & 72.6 & 2.4 & 0.6 & 3.0 & 50.2 \\
\hline NOR & $4.8-9.2$ & 1.4 & 84.2 & 13.9 & 0.5 & 14.4 & 41.7 \\
\hline $\mathrm{PR}$ & $7.3-11.0$ & 4.1 & 90.1 & 4.6 & 1.1 & 5.8 & 38.6 \\
\hline
\end{tabular}


Table 3. Results of micronizing experiment.

mode $(\mu \mathrm{m}) \quad$ median $(\mu \mathrm{m}) \quad$ mean $(\mu \mathrm{m}) \quad \%$ mud $(<62.5 \mu \mathrm{m}) \%$ clay $(<4 \mu \mathrm{m}) \%$ silt $(4 \mu \mathrm{m}-62.5 \mu \mathrm{m})$

\begin{tabular}{|c|c|c|c|c|c|c|}
\hline \multicolumn{7}{|l|}{ Anza Borrego } \\
\hline Starting material & 993 & 1080 & 1230 & 0.00 & 0.00 & 0.00 \\
\hline $5 \mathrm{sec}$ & 632 & 255 & 388 & 22.25 & 2.27 & 19.98 \\
\hline $10 \mathrm{sec}$ & 99.6 & 78.5 & 145 & 43.85 & 4.63 & 39.22 \\
\hline $15 \mathrm{sec}$ & 87.9 & 61.6 & 115 & 50.41 & 5.33 & 45.08 \\
\hline $30 \mathrm{sec}$ & 50.4 & 45.8 & 87.8 & 59.31 & 6.46 & 52.85 \\
\hline $45 \mathrm{sec}$ & 32.5 & 32.9 & 63.0 & 69.07 & 8.43 & 60.64 \\
\hline $1 \mathrm{~min}$ & 26.5 & 26.2 & 49.1 & 74.79 & 10.22 & 64.57 \\
\hline $5 \min$ & 8.04 & 8.17 & 16.5 & 94.90 & 27.22 & 67.68 \\
\hline \multicolumn{7}{|l|}{ Norway } \\
\hline Starting material & 845 & 894 & 990 & 0.00 & 0.00 & 0.00 \\
\hline $5 \mathrm{sec}$ & 814 & 140 & 419 & 33.34 & 3.35 & 29.99 \\
\hline $10 \mathrm{sec}$ & 170 & 49.3 & 122 & 56.61 & 6.13 & 50.48 \\
\hline $15 \mathrm{sec}$ & 69.2 & 48.6 & 81.4 & 58.11 & 5.82 & 52.29 \\
\hline $30 \mathrm{sec}$ & 38.1 & 36.4 & 64.0 & 66.92 & 7.62 & 59.30 \\
\hline $45 \mathrm{sec}$ & 28.1 & 23.5 & 46.6 & 81.29 & 10.84 & 70.45 \\
\hline $1 \mathrm{~min}$ & 24.7 & 19.0 & 28.5 & 89.24 & 12.85 & 76.39 \\
\hline $5 \mathrm{~min}$ & 10.8 & 9.35 & 18.0 & 94.27 & 23.44 & 70.83 \\
\hline \multicolumn{7}{|l|}{ Puerto Rico } \\
\hline Starting material & 782 & 805 & 877 & 0.49 & 0.00 & 0.49 \\
\hline $5 \mathrm{sec}$ & 594 & 201 & 335 & 27.45 & 2.87 & 24.59 \\
\hline $10 \mathrm{sec}$ & 97.5 & 68.8 & 147 & 47.47 & 5.17 & 42.30 \\
\hline $15 \mathrm{sec}$ & 80.6 & 52.6 & 109 & 54.80 & 6.11 & 48.69 \\
\hline $30 \mathrm{sec}$ & 40.1 & 38.1 & 86.1 & 65.34 & 7.22 & 58.13 \\
\hline $45 \mathrm{sec}$ & 31.9 & 28.9 & 95.4 & 73.28 & 8.87 & 64.41 \\
\hline $1 \mathrm{~min}$ & 24.9 & 19.0 & 33.2 & 88.47 & 13.31 & 75.16 \\
\hline $5 \mathrm{~min}$ & 6.89 & 5.90 & 20.7 & 96.40 & 35.49 & 60.91 \\
\hline
\end{tabular}


Table 4. Summary of previous studies.

\begin{tabular}{llll}
\hline $\begin{array}{l}\text { Simulated } \\
\text { process }\end{array}$ & Starting material & $\begin{array}{l}\text { Significant silt } \\
\text { produced? }\end{array}$ & Reference \\
\hline Glacial & Brazilian quartz & No & Wright (1995) \\
Glacial & Cretaceous sand & Yes & Kumar et al. (2006) \\
Glacial & Cretaceous sand & Yes & Jefferson et al. (1997) \\
Aeolian & Brazilian quartz & No & Kuenen (1960) \\
Aeolian & Vein quartz & Yes & Whalley et al. (1982) \\
\hline
\end{tabular}

